\section{Fahs-Beck Fund for Research and Experimentation}

909 Third Avenue, 22nd Floor, New York, NY 10022, United States of America.

Email:_james.herbert1@asu.edu

Website: www.fahsbeckfund.org/

\section{Doctoral Dissertation Grant Program (Fahs-Beck Scholars)}

Subjects: Problems in the functioning or well being of children, adults, couples, families, or communities, or about interventions designed to prevent or alleviate such problems.

Purpose: To help support dissertation expenses of doctoral students in the United States and Canada whose studies have the potential for adding significantly to knowledge about problems in the functioning or well being of children, adults, couples, families, or communities, or about interventions designed to prevent or alleviate such problems.

Eligibility: Applicants must be enrolled in an accredited doctoral program in the United States or Canada. The sponsoring organization must agree to accept administrative responsibility for the project and submit required financial forms and reports to the Fund.

Type: Grant

Value: Up to US $\$ 5,000$

Frequency: Twice a year

Country of Study: United States of America or Canada Application Procedure: Apply online

Closing Date: 1 November

Additional Information: www.fahsbeckfund.org/grant_pro grams.html

\section{Fanconi Anemia Research Fund, Inc.}

360 E. 10th Avenue, Suite 201, Eugene, OR 97401, United States of America.

Tel: $\quad$ (1) 5416874658

Email: info@fanconi.org

Website: www.fanconi.org

Contact: Fanconi Anemia Research Fund

To support research into effective treatments and a cure for Fanconi anemia.

\section{Fanconi Anemia Research Fund Award}

Purpose: To support research into effective treatments and a cure for Fanconi anemia

Eligibility: There are no restrictions on eligibility in terms of nationality, residency, age, gender, sexual orientation, race, religion or politics

Level of Study: Doctorate, Postdoctorate

Type: Award

Value: US\$10,000 for one-year

Length of Study: 1 years

Country of Study: Any country

Application Procedure: Applicants must email to obtain information and application forms

No. of awards offered: 29

Closing Date: 7 May

Funding: Foundation

Additional Information: The Internal Revenue Service has confirmed that the Fund is not a private foundation for the purposes of tax-exempt donations but a public charitable organization under 501(c) 3 of the Internal Revenue Code www.fanconi.org/explore/international-fa-support-grants 


\section{For further information contact:}

Email: grants@fanconi.org

\section{Federation University Australia}

Vice-Chancellor's Office, P.O. Box 663, University Drive, Mt Helen, VIC 3350, Australia.

Tel: $\quad$ (61) 53279000

Website: federation.edu.au

Contact: Sue Read

The University of Ballarat is Australia's only regional, multisector University acknowledged for its excellence in education, training, and research, committed to providing high quality services to students, the community, and the industry. It provides educational and training programs from apprenticeships, certificates and diplomas to postgraduate qualifications, masters, and doctorates by research. International students at the University come from over 25 different countries to participate in a diverse range of TAFE and higher education programmes. The University is proud of its track record in business innovation and entrepreneurship, research, consulting, and educational programs, and promoting new technology in products and services through scientific and industrial research.

\section{Australian Postgraduate Award}

Purpose: To support postgraduate students undertaking research in either a Doctorate or Masters by Research program

Eligibility: Open to candidates who have a First Class (Honours) Degree or equivalent. The APA is open to candidates who have received a Masters by Research (for Doctorate applicants) and/or a Honours degree (First Class/H1A) or equivalent

Level of Study: Doctorate, Postgraduate, Research

Type: Scholarship

Value: AU\$26,288 per year, Indexed annually

Frequency: Annual

Study Establishment: The University of Ballarat

Country of Study: Australia

Application Procedure: Application forms and further information about the Scholarships process can be found at feder ation.edu.au/research/research-degrees/scholarships

No. of awards offered: 130

Closing Date: 3 December
Funding: Government

Additional Information: It is required that the successful applicant commence studies in the year the scholarship was awarded for. Studies should commence no earlier than 1 February, and no later than 31 August www.fanconi.org/ explore/international-fa-support-grants

\section{For further information contact:}

Tel: $\quad$ (61) 353279508

Fax: (61) 353279602

Email: HDResearch@ballarat.edu.au

\section{Doctoral Research on Family Relationships}

Purpose: To undertake doctoral research on family relationships

Eligibility: Open to Australian citizens or permanent residents who have achieved First Class (Honours) or equivalent Level of Study: Postgraduate

Type: Scholarship

Value: AU\$19,231

Length of Study: 3 years and 6 months

Frequency: Annual

Study Establishment: The University of Ballarat

Country of Study: Australia

Application Procedure: Check website for further details. Applications are open from 25 July

Closing Date: 30 November

For further information contact:

Tel: $\quad$ (61) 353279818

Email: j.mcdonald@ballarat.edu.au

\section{Early Childhood Scholarships}

Purpose: To pursue a rewarding career as an early childhood teacher.

Eligibility: Scholarships are available for people looking to become an early childhood teacher through study in a degree or postgraduate qualification. Educators wanting to upskill and take the next step to become degree-qualified are also eligible. To be eligible for this scholarship you must be: 1 . An Australian citizen; or New Zealand citizen; or an Australian permanent resident 2. A continuing or new commencing student in the area of Early Childhood Education

Level of Study: Postgraduate

Type: Scholarship

Value: \$18,000

Frequency: Annual

Country of Study: Any country 
Application Procedure: See website www.education.vic. gov.au/ecscholarships

No. of awards offered: 400

Closing Date: 1 December

\section{Executive Dean's Postgraduate Scholarship}

Purpose: These scholarships are designed to encourage and reward excellence in postgraduate academic performance by School of Health students.

Eligibility: Academic merit 1. Where equal GPAs are attained, individual grades will be considered to determine recipients. 2. Students must be enrolled in $75 \%$ load to be eligible.

Level of Study: Postgraduate

Value: AU $\$ 800.00$

Country of Study: Any country

Application Procedure: Applications are not required as a selection panel will determine recipients based on GPA scores each Semester.

No. of awards offered: 8

\section{For further information contact:}

Tel: $\quad$ (61) 353279340

Email: scholarships@federation.edu.au

\section{International Excellence Scholarship}

Purpose: The International Excellence scholarships commencing 2020 are equivalent to $16 \%$ of your tuition fees.

Eligibility: 1. A prospective international student. 2. Eligible to study in Australia with a student visa. 3. Not have accepted, or be in receipt of, any other FedUni scholarship or bursary, or any other reduced fee arrangements at the time of entry to the University (with the exception of Federation University Accommodation Scholarships). 4. Not be in receipt of credit transfers or exemptions. 5. Meet minimum academic English entry requirement and offered with no more than 10 weeks English pathway program (e.g. academic IELTS overall 5.5 with no band less than 5.5 for general programs);. 6. Enrolling in an eligible program. 7. Enrolling in a program at a higher level than your existing qualification. 8. Studying full-time at a home campus of Federation University Australia. Home campuses are located in Ballarat, Gippsland and Berwick. These scholarships do not apply to students studying at a Federation University Partner Provider teaching location. Length of Study: The scholarship will apply for the normal duration of your program.

Closing Date: 31 August

\section{University of Ballarat Part Postgraduate Research Scholarship}

Eligibility: Open to citizens of Australia or permanent residents who have achieved First Class (Honours) or equivalent

Level of Study: Doctorate, Postgraduate, Research

Type: Scholarship

Value: AU\$22,500

Length of Study: 3 years (PhD and Professional Doctorate) and 1.5 years (Masters)

Frequency: Annual

Study Establishment: University of Ballarat

Country of Study: Australia

Application Procedure: Check website for further details. Applications are open from 03 January

Closing Date: 31 October

Funding: Commercial, Government

Additional Information: The study should start no earlier than 1 February www.fanconi.org/explore/international-fasupport-grants

For further information contact:

Tel: $\quad$ (61) 353279508

Fax: (61) 353279602

Email: s.murphy@ballarat.edu.au

\section{Fellowship Program in Academic Medicine}

National Medical Fellowship, Inc., 254 West 31st Street, New York, NY 10001, United States of America.

Contact: Awards Committee

\section{Akhtarali H. Tobaccowala Fellowship}

Purpose: The fellowship was established in the memory of Akhtarali H. Tobaccowala who was a 1952 graduate of the Booth school

Eligibility: The fellowship which offer tuition support is available for students of Booth's full-time MBA program

Level of Study: Postgraduate

Type: Scholarship

Value: Up to US\$25,000 per annum

Frequency: Annual

Country of Study: Any country 
Application Procedure: There is no formal application process Funding: Private

\section{For further information contact:}

The Tobaccowala Foundation, 35. Printing House, Police Court Lane (Behind Handloom House) Fort, Mumbai, Maharashtra 400 001, India.

Tel: (91) 2222640386

Email: tobaccowalafoundation@gmail.com

\section{Therla Drake Postgraduate Scholarships}

Purpose: The scholarship is for postgraduate classical performance overseas study and application should be made in the year for which the project is planned. While the terms of the bequest are that preference be given to a piano student, other applicants will be considered.

Eligibility: The project will normally involve the student attending a short online course. The project should be complementary to the current postgraduate course of study at the NZSM and create minimal disruption to any structured course work. This scholarship is open to NZ citizens, permanent residents and international students.

Level of Study: Postgraduate

Type: Scholarship

Value: Up to US $\$ 1,000$ per student

Frequency: Annual

Country of Study: Any country

Application Procedure: Applicants will complete the online application by the closing date. No late applications will be accepted. Applicants should provide the following supporting documentation: 1. A letter outlining the project and its benefit to your career plans. 2. A detailed budget. 3. Copies of any communication with the host person(s) or organisation (s) overseas. 4. A supporting statement from the principal supervisor. In order to proceed with the application, kindly check the below link. www.victoria.ac.nz/study/studentfinance/scholarships

Closing Date: 15 November

Funding: Private

Additional Information: www.wgtn.ac.nz/scholarships/cur rent/therle-drake-postgraduate-scholarship

\section{For further information contact:}

Scholarships Office, Victoria University of Wellington, PO Box 600, Wellington, 6140, New Zealand.

Email: scholarships-office@vuw.ac.nz

\section{Ferrari}

Direzione e stablimento Abetone int. 4, I-41053 Maranello (MO), Italy.

Tel: $\quad$ (39) 536949111

Email:_carrerservice@mip.polimi.it

Website: www.ferrariworld.com

Born in 1947, Ferrari has always produced vehicles at its current site and has maintained its direction. It has progressively widened it range using visionary planning to both on a design level and on the quality of work produced.

\section{Ferrari Innovation Team Project Scholarship}

Purpose: To create members of a new and innovative team for the new and innovative cars of the future

Eligibility: Knowledge of ergonomics will be considered a plus

Level of Study: Postgraduate, Professional development

Type: Scholarship

Value: $€ 25,000$ and all accommodation and training

Length of Study: 1 year

Frequency: Annual

Study Establishment: Ferrari Spa

Country of Study: Italy

Closing Date: 25 May

Funding: Commercial

Contributor: Ferrari

For further information contact:

Email: cdozio@ferrari.it

\section{Fight for Sight}

18 Mansell Street, London E1 8AA, United Kingdom.

Website: www.fightforsight.org.uk

\section{Fight for Sight}

Purpose: Fight for Sight is one of the leading United Kingdom charities dedicated to funding pioneering research to prevent sight loss and treat eye disease 
Eligibility: Young (under 40) ophthalmologists and scientists working in the field of ophthalmology in the United Kingdom - awarded recognition of the completion of a significant piece of research completed within 18 months prior to the closing date

Level of Study: Postgraduate

Type: Grant

Value: $£ 5,000$

Frequency: Annual

Country of Study: Any country

Closing Date: February

Funding: Foundation

Additional Information: www.eyedocs.co.uk/ ophthalmology-research-awards/1079-fight-for-sight-award

\section{For further information contact:}

Email: training@rcophth.ac.uk

\section{PhD Studentships}

Purpose: Fight for Sight's mission is to stop sight loss by funding the highest quality medical research. To help us achieve our goals we are committed to encouraging new and highly motivated graduates to take up and pursue a career in ophthalmic and vision research.

Eligibility: 1. Applications must be made by the potential PhD Supervisor(s). 2. Please note that Fight for Sight will only accept one PhD Studentship application from the same individual acting either as Supervisor or Co-Supervisor. 3. Supervisors must be affiliated with UK academic or medical institutions. 4. The Student must be attached to a UK institution but the research can be undertaken in the UK and/or overseas. 5. Supervisor(s) must have a contract which extends beyond the termination date of the PhD Studentship. 6. The Student appointed must not be medically or otherwise clinically qualified professionals. Clinically active individuals should consider the MRC / Fight for Sight Clinical Research Training Fellowships. 7. The scheme does not cover funding gaps for studentships already started. 8 . The proposed project must aim to stop or reduce sight loss.

Level of Study: Postgraduate

Type: Studentship

Value: Up to $£ 100,000$

Length of Study: three years

Closing Date: 11 June

Additional Information: www.fightforsight.org.uk/applyfor-funding/funding-opportunities/phd-studentships/

\section{For further information contact:}

Email: grants@fightforsight.org.uk

\section{Finnish National Agency for Education - EDUFI}

Hakaniemenranta 6, P.O. Box 380, FI-00531 Helsinki, Finland.

Tel: (358) 295331000

Website: www.oph.fi/

The Finnish National Agency for Education is the national development agency responsible for early childhood education and care, pre-primary, basic, general and vocational upper secondary education as well as for adult education and training. Higher education is the responsibility of the Ministry of Education and Culture.

\section{EDUFI Fellowship}

Purpose: The EDUFI Fellowships programme is open to young Doctoral level students and researchers from all countries and from all academic fields who wish to pursue their Doctorate (or Double Doctorate) at a Finnish university. Master's level studies or post-doctoral studies/research are not supported in the programme.

Eligibility: You can apply for the fellowship grant if 1 . you work as a researcher or a teacher in a Finnish university department 2. you will be hosting the research fellow 3. you will commit to common objectives with the research fellow 4 . you will offer facilities and equipment for the use of the research fellow 5. you will supervise the research. 6. You can apply for a fellowship for a non-Finnish post-graduate (post Master's degree) student or a young researcher that you will invite to Finland or who has been in Finland for a maximum of one year before applying for the fellowship. The EDUFI Fellowship is available to all foreign nationals and all fields of study.

Level of Study: Masters Degree

Type: Scholarships

Value: $€ 1,500$

Length of Study: 3-12 months, visits 3-6 months

Frequency: Annual

Country of Study: Finland

Application Procedure: You can fill in the EDUFI Fellowship application form in Finnish, Swedish or English. The application form comes with instructions on how to fill it and a list of required annexes. Please post two copies of the form and annexes. Address EDUFI, EDUFI Fellowship, P.O. Box 380, 00531 Helsinki, Finland.

Additional Information: www.oph.fi/en/development/ edufi-fellowship 


\section{Five Strong Scholarship Foundation}

\section{Email: 5strongscholars@gmail.com}

Website: www.5strongscholars.org

The 5 Strong Scholarship Foundation's vision is to help increase retention and graduation rates of Historically Black Colleges and Universities by placing groups of 5 Strong Scholars on these campuses nationwide each year. With the support offered by the 5 Strong Foundation, these groups of 5 Strong Scholars will become equipped with the academic, professional, and social tools that position them to be leaders on their campuses, leaders in their communities and leaders in the international workforce.

\section{Strong Scholarship}

Subjects: Must attend one of our partnering HBCUs

Purpose: To provide full tuition and ongoing support to promising student leaders from the Metropolitan Atlanta and Houston areas. 5 Strong focuses on students in the "Academic Middle" (great grades but low to average test scores).

Eligibility: Must be a graduating senior in Metro Atlanta or Houston. Minimum 3.0 GPA, 19 ACT, 990 SAT required.

Level of Study: Undergraduate

Type: Scholarship

Value: 4 year Full tuition

Length of Study: 4 years

Frequency: Annual

Country of Study: United States of America

No. of awards offered: 40

Closing Date: 1 December

Funding: Foundation

Contributor: The HBCUs

Additional Information: www.scholarships.com/financialaid/college-scholarships/scholarships-by-type/full-tuitionscholarships/5-strong-scholarship/

\section{For further information contact:}

Andrew H. Ragland, 103 Pinegate Road, Peachtree City, GA 30269, United States of America.

Tel: (1) 7708736621

\section{Flinders University}

GPO, Box 2100, Adelaide, SA 5001, Australia.

Tel: $\quad$ (61) 882012916

Email: newsdesk@flinders.edu.au

Website: www.flinders.edu.au
Flinders University is an integral part of Australia's respected higher education system and makes an important economic and social contribution to South Australia and to the nation. Flinders has a high research profile and consistently ranks among Australia's top universities on a per capita basis for research. It emphasizes innovation and excellence in its educational programs and researches across a wide range of disciplines.

\section{Advanced Community Care Scholarship}

Purpose: To undertake a research project within the Faculty of Health Sciences related to the practical clinical, organizational and financial implications of home-based alternatives to hospital care

Eligibility: Applicants must be Australian citizens or permanent residents of Australia and have completed at least 4 years of tertiary education studies at a high level of achievement and have an appropriate Honours 1 or high 2A (or equivalent) undergraduate degree. They must enroll as full-time students (part-time awards are available in certain circumstances)

Level of Study: Postgraduate

Type: Scholarship

Value: AU $\$ 19,616$ per year

Length of Study: 3 years

Application Procedure: Applicants must obtain the application kits from the Higher Degree Administration and Scholarships Office or can download it from the scholarships website Closing Date: 31 October

Contributor: Advanced Community Care Association

\section{For further information contact:}

Tel: (61) 882013115

Email: scholarships@flinders.edu.au

\section{Australian Health Inequities Program Research Scholarship}

Purpose: To address health inequities, understand the social determinants of health and analyze policy and program strategies that aim to reduce inequities

Eligibility: Applicants should be Australian citizens, permanent residents of Australia or New Zealand citizens and have completed at least four years of tertiary education studies at a high level of achievement and have an appropriate Honours 1 or high $2 \mathrm{~A}$ (or equivalent) undergraduate degree. They should enroll as full-time students (a part-time award may be available in certain circumstances) and should commence a Doctorate by research

Level of Study: Postgraduate

Type: Scholarship 
Value: AU \$19,616 per year

Length of Study: 3 years

Application Procedure: Applicants can obtain the application kits from the Higher Degree Administration and Scholarships Office or download it from Flinders University scholarships website

Closing Date: 31 October

\section{For further information contact:}

Department of Public Health.

Tel: $\quad$ (61) 882045983

Email: fran.baum@fllinders.edu.au

\section{Australian Health Inequities Program University Research Scholarship}

Purpose: To address health inequities, to understand the social determinants of health and to analyze policy and program strategies that aim to reduce them

Eligibility: Applicants must be Australian citizens, permanent residents of Australia or New Zealand citizens and have completed at least 4 years of tertiary education studies at a high level of achievement and have an appropriate Honours 1 or high $2 \mathrm{~A}$ (or equivalent) undergraduate degree. They should enroll as full-time students (a part-time award may be available in certain circumstances) and should commence a Doctorate by research

Level of Study: Postgraduate

Type: Scholarship

Value: AU\$19,616 per year

Length of Study: 3 years

Application Procedure: Applicants can obtain the application kits from the Higher Degree Administration and Scholarships Office or download it from Flinders University scholarships website. It is essential to consult Prof. Baum or Dr. Newman before submitting an application

Closing Date: 31 October

\section{For further information contact:}

Department of Public Health.

Tel: $\quad$ (61) 882045983

Email: fran.baum@flinders.edu.au

\section{Diamond Jubilee Bursary}

Purpose: It is helpful for women, who are Australian citizens or permanent residents, enrolled in a postgraduate Masters degree (by research or including a thesis) at a South Australian university
Eligibility: Applicants: 1. Women students who are Australian citizens or permanent residents. 2. Must be studying at a South Australian University for a postgraduate award which is classified. 3. at Masters Degree level. This must be by research or include a thesis component. 4. Must have completed at least six months full time equivalent of their masters program. 5. Must have a good undergraduate academic record. 6. Must not be in full time paid employment or on fully paid leave during the tenure of the Scholarship. 7. Must not have received a scholarship or award in the same category

Level of Study: Postgraduate

Type: Bursary

Value: AU $\$ 4,000$

Length of Study: 1 year

Frequency: Annual

Country of Study: Australia

Application Procedure: Application forms can be downloaded from the AFUW-SA website listed below. 1. Your application must reach the Trust Fund's secretarial service by 29 March. 2. Scholarship Type: postgraduate, academic merit, financial, commencing, continuing

Closing Date: 31 March

Funding: Private

Additional Information: Selection of winners is based primarily on academic merit, but also on the importance of the purpose for which the scholarship will be used to the progress or completion of the degree, on referees' report, on financial need as well as community activities and other interests www. afuwsa-trust.com.au/dj-scholarships/

\section{For further information contact:}

The AFUW-SA Inc. Trust Fund, 213 Greenhill Road, Eastwood, SA 5063, Australia.

Email: internationalapply@flinders.edu.au

\section{Faculty of Science and Engineering Research Awards (FSERA)}

Purpose: To enable students to pursue a Masters Degree by research or Doctorate by research in the Faculty of Science and Engineering

Eligibility: Applicants should have achieved Honours 1 or equivalent, or Honours 2a or equivalent. Only citizens of Australia or New Zealand or permanent residents can apply Level of Study: Graduate, Postgraduate

Type: Research award

Value: AU $\$ 19,616$ per year

Length of Study: 2 years if masters or 3 years if $\mathrm{PhD}$

Country of Study: Australia 
Application Procedure: Applicants must apply directly to the university

Closing Date: 31 October

Additional Information: scholarship-positions.com/facultyscience-engineering-research-scholarships-fsera-flinders-uni versity-australia/2017/05/26/

\section{For further information contact:}

Tel: $\quad$ (61) 882013115

Fax: (61) 882015175

Email: scholarships@flinders.edu.au

\section{Flinders University Research Scholarships (FURS)}

Purpose: To enable suitably qualified applicants to proceed to a full-time Masters by research or Doctorate by research

Eligibility: Applicants must have achieved Honours 1 or equivalent, or Honours $2 \mathrm{a}$ or equivalent. Only citizens of Australia or New Zealand or permanent residents can apply

Level of Study: Postgraduate

Type: Scholarship

Value: AU\$19,616

Length of Study: 2 years for masters or 3 years for $\mathrm{PhD}$

Frequency: Annual

Country of Study: Australia

Application Procedure: Applicants must apply directly to the university

Closing Date: 31 October

Additional Information: www.australianuniversities.com au/scholarships/guide/8495-flinders-university-research-scholar ship-furs.html

\section{For further information contact:}

Tel: $\quad$ (61) 882013115

Fax: (61) 882015175

Email: scholarships@flinders.edu.au

\section{FMC Foundation Pink Ribbon Ball Committee Breast Cancer Research Scholarship}

Purpose: To undertake a breast cancer biomedical research project within the Faculty of Health Sciences

Eligibility: Applicants must be Australian citizens or permanent residents of Australia and have completed at least 4 years of tertiary education studies at a high level of achievement and have an appropriate Honours 1 or high 2A (or equivalent) undergraduate degree. They must enroll as full-time students (part-time awards are available in certain circumstances) and must commence a Doctorate by research
Level of Study: Postgraduate

Type: Scholarship

Value: AU\$25,000 plus up to AU\$2,000 per year for conference travel and consumables

Length of Study: 3 years

Frequency: Annual

Application Procedure: Applicants can obtain the application kits from the Higher Degree Administration and Scholarships Office and can download it from the scholarship website

Closing Date: 31 October

Contributor: Flinders Medical Centre Foundation

Additional Information: breastcancernow.org/get-involved/ social-events/pink-ribbon-ball-london

\section{For further information contact:}

Tel: (61) 882044100

Email: johnno.oliver@flinders.edu.au

\section{FMC Foundation Research Scholarship}

Purpose: To undertake a health-related project within the Faculty of Health Sciences

Eligibility: Applicants should be Australian citizens or permanent residents of Australia and have completed at least 4 years of tertiary education studies at a high level of achievement and have an appropriate Honours 1 or high 2A (or equivalent) undergraduate degree. They should enroll as full-time students (part-time awards are available in certain circumstances) and should commence a Doctorate by research

Level of Study: Postgraduate

Type: Scholarship

Value: AU\$25,000 plus up to AU\$2,000 per year for conference travel and consumables

Length of Study: 3 years

Frequency: Annual

Application Procedure: Applicants can obtain application kits from the Higher Degree Administration and Scholarships Office or download from the scholarships website

Closing Date: 31 October

Funding: Foundation

Contributor: FMC Foundation

Additional Information: www.flinders.edu.au/scholarshipssystem/index.cfm/scholarships/display/a0502

\section{For further information contact:}

Tel: $\quad$ (61) 882044100

Email: johnno.oliver@flinders.edu.au 


\section{Honours/Masters Scholarship for Al, User Interface or Robotics}

Purpose: To enable students to undertake an Honours or Masters project in the Artificial Intelligence Laboratory in the School of Informatics and Engineering at Flinders University

Eligibility: Applicants must have Australian citizenship or permanent residence, plus distinction-level completion of the requirements of 3 years of undergraduate degree in cognitive science, computer science, mathematics, or engineering program

Level of Study: Graduate

Type: Scholarship

Value: AU $\$ 5,000$

Application Procedure: Check website for further details

Closing Date: 15 November

For further information contact:

Email: David.Powers@flinders.edu.au

\section{Investigation of the Human Intestinal Nervous System}

Purpose: To support investigation of the human intestinal nervous system

Eligibility: Applicants must be Australian citizens or permanent residents of Australia and have completed at least 4 years of tertiary education studies at a high level of achievement and have an appropriate undergraduate medical degree. They should enroll as full-time students and commence a Doctorate by research

Level of Study: Graduate

Type: Scholarship

Value: AU $\$ 29,172$

Length of Study: 3 years

Frequency: Annual

Application Procedure: Applicants can obtain application kits from the Higher Degree Administration and Scholarships Office or can download from the scholarships website

Closing Date: 31 October

\section{For further information contact:}

Tel: $\quad$ (61) 882044253

Email: david.wattchow@flinders.edu.au

\section{May Mills Scholarship for Women}

Purpose: The purpose of the scholarship is to encourage women who have experienced significant interruptions to their studies due to family responsibilities, to proceed to a research higher degree at Flinders University. The scholarship covers programs of study that will qualify women for admission to a research higher degree, such as honours, postgraduate coursework studies or bridging studies programs.

Eligibility: Applicants must be female citizens or permanent residents of Australia

Level of Study: Graduate, Postgraduate

Type: Scholarship

Value: Maximum AU $\$ 9,000$ per year

Length of Study: 1 year

Frequency: Annual

Country of Study: Australia

Application Procedure: Applicants may consult the scholarship website

Closing Date: 31 January

Contributor: Flinders University

Additional Information: www.scholarshipcare.com/maymills-scholarship-for-women/

For further information contact:

Tel: $\quad$ (61) 882013143

Fax: (61) 882015175

Email: scholarships@flinders.edu.au

\section{Multi Scale Biomechanical Investigations of the Intervertebral Disc}

Purpose: To undertake a challenging program of research that combines both analytical (finite element analysis) and experimental

Eligibility: Applicants must be Australian or international students who have completed at least 4 years of tertiary education studies at a high level of achievement and have an appropriate Honours 1 or high 2A (or equivalent) undergraduate degree in mechanical/biomedical/civil/chemical engineering or related fields

Level of Study: Postgraduate

Type: Scholarship

Value: AU $\$ 25,313$

Length of Study: 3 years

Frequency: Annual

Application Procedure: Applicants can obtain the application kits from the Higher Degree Administration and Scholarships Office at Flinders University

Closing Date: 1 June

For further information contact:

Tel: $\quad$ (61) 882751751

Email: john.costi@rgh.sa.gov.au 


\section{National Health and Medical Research Council Centre of Clinical Eye Research: PhD Scholarships}

Purpose: To conduct clinical research in the major blinding diseases - cataract, glaucoma, diabetic retinopathy and corneal disease

Eligibility: Applicants must be Australian citizens, permanent residents of Australia or New Zealand citizens and have completed at least 4 years of tertiary education studies at a high level of achievement and have an appropriate Honours 1 or high 2A (or equivalent) undergraduate degree

Level of Study: Postgraduate

Type: Scholarship

Value: A stipend of AU\$20,007-29,172 plus AU\$2,000 for conference travel and consumables

Length of Study: 3 years

Frequency: Annual

Application Procedure: Applicants can obtain the application kits from the Higher Degree Administration and Scholarships Office or can download it from the scholarships website

Closing Date: 31 October

For further information contact:

Tel: $\quad$ (61) 882044899

Email: Konrad.Pesudovs@flinders.edu.au

\section{National Health and Medical Research Council Medical and Dental Postgraduate Research Scholarships}

Purpose: To provide full-time research experience to medical or dental graduates registered to practice in Australia

Eligibility: Applicants must be medical or dental graduates registered to practice in Australia. Graduates from overseas who hold permanent resident status and are currently resident in Australia are eligible to apply

Level of Study: Graduate

Type: Scholarship

Value: AU\$29,172 per year plus AU\$2,250 per year towards the cost of consumables and travel to approved conferences

Length of Study: 3 years

Country of Study: Australia

Application Procedure: Applicants can obtain application forms, instruction booklets, referee report pro formae and various attachments to the instructions from the NHMRC website

Closing Date: 25 July

\section{For further information contact:}

Email: research@nhmrc.gov.au

\section{National Health and Medical Research Council Public Health Postgraduate Scholarships}

Purpose: To encourage graduates to obtain formal training in public health research

Eligibility: Applicants must be Australian citizens who have already completed a degree in an area applicable in public health research at the time of submission of the application or graduates in areas applicable to public health who are from overseas, have permanent resident status and are currently residing in Australia. All candidates must enroll for a higher degree requiring full-time research

Level of Study: Graduate

Type: Scholarship

Value: AU\$19,616 (Australian postgraduate award), AU\$25,313 (nursing and allied health professionals) and AU\$29, 172 (medical/dental)

Frequency: Annual

Country of Study: Australia

Application Procedure: Applicants must submit the application forms to the Higher Degree Administration and Scholarships Office and should include one additional copy for University records. Application forms, instruction booklets, referee report pro formae and various attachments to the instructions are available from the NHMRC website

Closing Date: June

\section{For further information contact:}

Tel: $\quad$ (61) 286271444

Email: research@nhmrc.gov.au

\section{National Health and Medical Research Council: Primary Health Care Postgraduate Research Scholarships}

Purpose: To encourage graduates to obtain formal training in primary health care related research, with an emphasis on rural communities

Eligibility: Applicants must be Australian citizens or have permanent resident status, who are medical, dental or healthrelated graduates currently registered to practice within Australia or who have already completed a degree (or equivalent) at the time of submission of the application Level of Study: Graduate

Type: Scholarship

Value: AU\$19,616 (Australian postgraduate award), AU\$25,313 (nursing and allied health professionals) and AU\$29, 172 (medical/dental) per year

Country of Study: Australia

Application Procedure: Applications must be submitted to the Higher Degree Administration and Scholarships Office 
and should include one additional copy for University records. Application forms, instruction booklets, referee report pro formae and various attachments to the instructions are available from the NHMRC website

Closing Date: 25 July

For further information contact:

Email: research@nhmrc.gov.au

\section{PhD Scholarship for Vascular and Metabolic Research}

Purpose: To focus on the relationship between obesity, adipose tissue distribution, endothelial function and cardiovascular risk in humans using established techniques such as liver MRI and spectroscopy, pulse-wave analysis, and forearm occlusion plethysmography

Eligibility: Applicants should be Australian citizens or permanent residents of Australia and have completed at least 4 years of tertiary education studies at a high level of achievement and have an appropriate undergraduate medical degree Level of Study: Postgraduate

Type: Scholarship

Value: AU\$20,007 per year

Length of Study: Up to 3 years

Frequency: Annual

Study Establishment: Faculty of Health Sciences, Flinders University

Country of Study: Australia

Application Procedure: Applicants can obtain the application kits from the Higher Degree Administration and Scholarships Office or can download it from the scholarships website Closing Date: 31 October

For further information contact:

Tel: $\quad$ (61) 882045202

Email: arduino.mangoni@flinders.edu.au

\section{Professor Lowitja O'Donoghue Indigenous Student Postgraduate Research Scholarship}

Purpose: To enable suitably qualified applicants to proceed to a full-time Masters by research or Doctorate by research Eligibility: Applicants must be Australian citizen, must have achieved Honours 1 or equivalent or Honours 2a or equivalent and must be an Aboriginal or Torres Strait Islander Level of Study: Graduate

Type: Scholarship

Value: AU\$25,627

Length of Study: 2 years if Masters and 3 years if $\mathrm{PhD}$
Frequency: Annual

Study Establishment: Flinders University

Country of Study: Australia

Application Procedure: Applicants must apply directly to the university

Closing Date: 31 October

For further information contact:

Tel: $\quad$ (61) 882013115

Fax: (61) 882015175

Email: scholarships@flinders.edu.au

\section{Reconciliation SA Aboriginal Education Leaders Fund Postgraduate Research Scholarship}

Purpose: To foster leadership potential and skill development and to promote the vision of the Council for Aboriginal Reconciliation in South Australia

Eligibility: Applicants must have applied for admission to, or be enrolled in, a research higher degree on a full or part-time basis at Flinders University, University of Adelaide or University of South Australia and normally reside in South Australia and be of Australian Aboriginal or Torres Strait Islander descent and be identified and be accepted as an Australian Aboriginal or Torres Strait Islander by the community in which he or she lives or has lived

Level of Study: Graduate

Type: Scholarship

Value: AU $\$ 5,000$

Frequency: Annual

Application Procedure: Applicants must contact the Yunggorendi First Nations Centre for Higher Education for further information and application forms

Closing Date: 31 January

For further information contact:

Email: shane.carr@flinders.edu.au

\section{Repatriation General Hospital Department of Rehabilitation and Aged Care: Health Professionals Research Scholarship}

Purpose: To undertake research in an area of rehabilitation (cerebral palsy, driving rehabilitation, hydrotherapy, multiple sclerosis rehabilitation, hip fracture recovery)

Eligibility: Applicants must normally be Australian citizens, permanent residents of Australia or New Zealand citizens, who hold a First Class or upper Second Class Honours Degree in an appropriate health-related discipline, or an equivalent qualification 
Level of Study: Graduate

Type: Scholarship

Value: AU $\$ 25,000-29,172$

Length of Study: 3 years

Frequency: Annual

Application Procedure: Applicants can obtain the application kits and further information from the scholarships web site or from the Higher Degree Administration and Scholarships Office

Closing Date: 7 January

For further information contact:

Tel: $\quad$ (61) 882751103

Email: maria.crotty@rgh.sa.gov.au

\section{Repatriation General Hospital Department of Rehabilitation and Aged Care: Medical Research Scholarship}

Purpose: To join a world class research team and improve health care

Eligibility: Applicants must be medical graduates and normally Australian citizens, permanent residents of Australia or New Zealand citizens, who hold a First Class or upper Second Class Honours Degree in an appropriate health-related discipline, or an equivalent qualification

Level of Study: Graduate

Type: Scholarship

Value: AU $\$ 29,172$

Length of Study: 3 years

Application Procedure: Applicants can obtain the application kits and further information from the scholarships web site or from the Higher Degree Administration and Scholarships Office

Closing Date: 31 October

For further information contact:

Tel: $\quad$ (61) 882751103

Email: maria.crotty@rgh.sa.gov.au

\section{Repatriation General Hospital Department of Rehabilitation and Aged Care: Nursing Research Scholarship}

Eligibility: Applicants must be nursing graduates and normally Australian citizens, permanent residents of Australia or New Zealand citizens, who hold a First Class or upper Second Class Honours Degree in an appropriate health-related discipline, or an equivalent qualification

Level of Study: Graduate

Type: Scholarship
Value: AU\$25,000-29,172 per year

Length of Study: 3 years

Application Procedure: Applicants can obtain the application kits and further information from the scholarships web site or from the Higher Degree Administration and Scholarships Office

Closing Date: 31 October

\section{For further information contact:}

Tel: (61) 882751103

Email: maria.crotty@rgh.sa.gov.au

\section{South Australian Department of Health Research Award}

Purpose: To undertake a research project relevant to the health of South Australians, the South Australian health system, or the health-related targets in South Australia's Strategic Plan

Eligibility: Applicants must have achieved Honours 1 or equivalent, or Honours 2a or equivalent. Only citizens of Australia or permanent residents can apply

Level of Study: Postgraduate

Type: Scholarship

Value: AU $\$ 19,231$ per year

Length of Study: 3 years

Frequency: Annual

Country of Study: Australia

Application Procedure: Applicants must apply directly to the university

Closing Date: 31 October

For further information contact:

Tel: $\quad$ (61) 882013115

Fax: (61) 882015175

Email: scholarships@flinders.edu.au

\section{The Jack Loader Top-Up Scholarship}

Purpose: To encourage research into dementia, in particular Alzheimer's Disease, and related disorders and/or the consequences of these diseases

Eligibility: Applicants must be Australian citizens or permanent residents of Australia and be enrolled full time in a research degree at one of the South Australian universities. Applicants should have received an Australian Postgraduate Award or equivalent University Scholarship

Level of Study: Graduate

Type: Scholarship

Value: AU\$ $\$, 000$

Length of Study: 12 months

Frequency: Annual 
Application Procedure: Check website for further details

Closing Date: 31 October

Funding: Foundation

Contributor: The Rosemary Foundation for Memory Sup-

port Inc and Alzheimer's Australia South Australia

For further information contact:

Email: jmck1279@bigpond.net.au

\section{University Hall Dean's Scholarship}

Eligibility: Applicants must be resident in University Hall and enrolled in a degree course at the Flinders University at the time of application. Only citizens of Australia or New Zealand living in Australia over 1 year can apply

Level of Study: Graduate

Type: Scholarship

Value: AU $\$ 2,000$ per year

Length of Study: 1 year

Frequency: Annual

Country of Study: Australia

Application Procedure: Applicants must apply directly to the scholarship provider

Closing Date: 20 October

For further information contact:

Tel: $\quad$ (61) 882013115

Fax: (61) 882015175

Email: scholarships@flinders.edu.au

\section{University Hall Eurest Overseas Study Scholarship}

Purpose: To enable full-time students residing in University Hall, who have demonstrated outstanding aptitude for research, to undertake a period of further study or research in approved universities or other institutions outside Australia Eligibility: Applicants must have lived in University Hall for a period of not less than one academic year, have gained unqualified support for his/her supervisor for the proposed overseas visit, have gained approval from the overseas institution that he/she is acceptable for the proposed period of study and have demonstrated a suitable academic record in the previous academic year

Level of Study: Postgraduate

Type: Scholarship

Value: AU $\$ 2,500$

Length of Study: 1 year

Frequency: Annual

Application Procedure: Applicants must contact the Higher Degree Administration and Scholarships Office and University Hall for application forms and further information
Closing Date: 20 October

\section{For further information contact:}

Email: flinders.housing@flinders.edu.au

\section{Winifred E. Preedy Postgraduate Bursary}

Purpose: The aim of this scholarship is to assist women to undertake and complete higher degrees in dentistry or an allied field, either via coursework or research.

Eligibility: 1. Applications are invited from women who are enrolled at an Australian university and who: 2. are enrolled in a Master's Degree or a PhD in dentistry or a related field; 3. are Australian citizens or permanent residents; 4. have completed at least one year of their postgraduate degree; 5. are past or present students in the Dental School at the University of Adelaide; 6. are not in full-time paid employment or on fully-paid leave during the tenure of the scholarship; 7. have not previously won the Winifred E. Preedy Postgraduate Scholarship The scholarship may be held concurrently with awards offered by organisations other than the AFUW-SA Inc. Trust Fund.

Level of Study: Postgraduate

Type: Bursary

Value: AU\$2,000

Frequency: Annual

Country of Study: Australia

Closing Date: 31 March

Funding: Private

Additional Information: www.afuwsa-trust.com.au/weppscholarship/\#: : text=Recent $\% 20$ Winners-,Winifred $\% 20 \mathrm{E} \%$ 20Preedy $\% 20$ Postgraduate $\% 20$ Scholarship,either $\% 20 v i a \%$ 20 coursework\%20or\%20research.

\section{For further information contact:}

Email: bursaries@afuwsa-trust.com.au

\section{Fogarty International Center}

Fogarty International Center, National Institutes of Health, 31 Center Drive, MSC 2220, Bethesda, MD 20892-2220, United States of America.

Website: www.fic.nih.gov

The Fogarty International Center is dedicated to advancing the mission of the National Institutes of Health (NIH) by supporting and facilitating global health research conducted by U.S. and international investigators, building partnerships between health 
research institutions in the U.S. and abroad, and training the next generation of scientists to address global health needs.

\section{African Association for Health Professions Education and Research}

Purpose: The African Association for Health Professions Education and Research builds on the Medical Education Partnership Initiative (MEPI) and the Nursing Education Partnership Initiative (NEPI)

Eligibility: 1. Non-African partners may not be listed as Multiple Principal Investigators. 2. An international African consortium of committed institutions should submit an application together and form the basis for the founding network leadership. 3. Named participating institutions for the establishment of the Association must include at least one former MEPI awardee institution (programmatic, linked or pilot awards) and at least one former NEPI awardee institution; but are not limited to these institutions

Level of Study: Postgraduate

Type: Grant

Frequency: Annual

Country of Study: Any country

Closing Date: 28 March

Funding: Private

\section{For further information contact:}

Tel: (61) 3014029591

Email: flora.katz@nih.gov

\section{Chronic, Noncommunicable Diseases and Disorders Research Training (NCD-Lifespan)}

Purpose: The Chronic, Noncommunicable Diseases and Disorders Across the Lifespan: Fogarty International Research Training Award program supports collaborative research training between institutions in the United States and low-and middle-income countries (LMICs), defined by the World Bank classification system

Eligibility: 1. Applications from United States institutions must demonstrate collaborations with institutions in the lowand middle-income countries (LMICs), defined by the World Bank classification system, named in their application. 2. Foreign applications will only be accepted from LMIC institutions. 3. Only foreign LMIC institutions may apply for the D71 planning grant. 4. United States applicants must identify at least one scientist from each LMIC institution as the main foreign collaborator for that institution

Level of Study: Graduate

Type: Research grant
Frequency: Annual

Country of Study: Any country

Closing Date: 13 November

Funding: Private

\section{For further information contact:}

Division of International Training and Research, Fogarty International Center, National Institutes of Health, Building 31, Room B2C39, Bethesda, MD 20892-2220, United States of America.
Tel:
(1) 3014961653
Fax: (1) 3014020779
Email: Kathleen.Michels@nih.gov

\section{Ernst Mach Grant for Young Researchers}

Purpose: 1. The Ernst Mach grant is named after the famous Austrian physicist. Student and young researchers from foreign universities are invited to apply for this grant to come to Austria for research. 2. It promote research cooperation Eligibility: 1. Very good knowledge of English/German Level of Study: Graduate

Type: Grant

Value: For graduates with $\mathrm{PhD}$ degree the value is $€ 1,150$

Frequency: Annual

Country of Study: Any country

Application Procedure: 1. Applicants who seek admission to an university in Austria have to contact the institution of their choice. 2. The selection process for all grants is competitive, i.e., there is no legal claim to a grant even if all the application requirements are fulfilled. 3. Short-term grants (1-3 months) have a priority in the period from January to June. When applying for a short-term grant therefore consideration should be given primarily for a period of January to June

Closing Date: 30 September

Funding: Private

For further information contact:

Tel: (61) 1534080

\section{H3Africa Global Health Bioinformatics Research Training Program}

Purpose: Through the Human Heredity and Health in Africa (H3Africa) Initiative, the Global Health Bioinformatics Research Training Program supports bioinformatics research training programs at low- and middle-income country (LMIC) institutions in Africa with significant genomics research capacity 
Eligibility: H3Africa fosters genomic and epidemiological research in African scientific institutions

Level of Study: Postgraduate

Type: Programme grant

Frequency: Annual

Country of Study: Any country

Application Procedure: The training programs address the need for bioinformatics research expertise in the H3Africa Consortium, resulting in sustainable centers of bioinformatics research training relevant to global health research for the African continent

Funding: Private

\section{For further information contact:}

Tel: $\quad$ (1) 3018272227

Fax: (1) 3014020779

Email: laura.povlich@nih.gov

\section{Fondation des Etats-Unis}

15 Boulevard Jourdan, F-75014 Paris, France.

Tel: $\quad$ (33) 153806880

Email:_administration@feusa.org

Website: www.feusa.org

Contact: Mr Sophie Uasset, Director

For the past 75 years the Fondation des Etats-Unis has been welcoming American and International Students during their studies in Paris.

\section{Harriet Hale Woolley Scholarship}

Purpose: To support the study of visual arts, music and psychiatry in Paris

Eligibility: Open to citizens of the United States of America, who are 21-30 years of age and have graduated with high academic standing from a United States college, university or professional school of recognized standing. Applicants should provide evidence of artistic or musical accomplishment. Applicants should have a good working knowledge of French, sufficient to enable the student to benefit from his or her study in France. Grants are for those studying painting, printmaking or sculpture and for instrumentalists, not for research in art history, musicology or composition, nor for students of dance or theatre. Successful candidates propose a unique and detailed project related to their study, which requires a 1-year residency in Paris
Level of Study: Doctorate, Graduate, Postgraduate, Predoctorate Type: Scholarship

Value: A stipend of around US $\$ 10,000$ (subject to fund earnings)

Length of Study: 1 academic year

Frequency: Annual

Country of Study: France

Application Procedure: For a complete description of the scholarship including a list of general requirements, an application checklist and an application form, please visit www. feusa.org/harriet-hale-woolley-scholarship

Closing Date: 31 January

Funding: Private

\section{For further information contact:}

Fondation des Etats-Unis, 15 Boulevard Jourdan, F-75014 Paris, France.

Tel: (33) 153806882

Email: culture@feusa.org

\section{Fondation Fyssen}

194 Rue de Rivoli, F-75001 Paris, France.

Tel: $\quad$ (33) 142975316

Email: secretariat@fondation-fyssen.org

Website: www.fondation-fyssen.org

Contact: Mrs Nadia Ferchal, Director

The aim of the Fyssen Foundation is to encourage all forms of scientific enquiry into cognitive mechanisms, including thought and reasoning, that underlie animal and human behaviour, their biological and cultural bases and phylogenetic and ontogenetic development.

\section{International Prize}

Purpose: To encourage a scientist who has conducted distinguished research in the areas supported by the Foundation Eligibility: Applicants are requested to visit the website Value: $€ 60,000$

Frequency: Annual

Country of Study: Any country

Application Procedure: Candidates cannot apply directly but should be proposed by recognized scientists. Proposals for candidates should consist of (i) curriculum vitae, (ii) a list of publications, (iii) a summary ( 4 pages maximum) of the 
research. The proposal should be submitted in 14 copies to Secrétariat de la Fondation Fyssen

Closing Date: 6 November

Funding: Private

\section{Fondation Jeunesse Internationale, Ecole Franchaise d'Extreme-Orient}

Tel: $\quad$ (33) 153701860

Email: contrats.postdocs@efeo.net

Contact: Ms Evelise Bruneau

\section{Short-Term EFEO Postdoctoral Contracts}

Eligibility: 1. Fellowships are offered in the fields of the Humanities and Social Sciences (Anthropology, Literature and Art Studies, History, Geography, Philosophy, Political Science, Sociology, etc.) 2. Applicants must have obtained a PhD following a viva voce examination held in or after 2013. There is no age limit. 3. Successful applicants must hold a bank account in France. 4. Applicants should have a good command of the language(s) required to successfully complete the research project. 5. The postdoctoral fellowships cannot be combined with any other full-time salaried employment

Value: $€ 1,500$

Length of Study: 3 to 6 months

Country of Study: France

Application Procedure: Applications may be submitted in French or English. Applications should be in PDF format (one document only) entitled NAME Surname Candidature Postdocs EFEO

Closing Date: 14 October

Additional Information: For further information, please contact Ms. Evelise Bruneau (contrats.postdocs@efeo.net) www.efeo.fr/base.php?code $=971$

For further information contact:

Fax: (33) 153701860

\section{Ford Foundation}

320 East 43rd Street, New York, NY 10017, United States of America.

Tel: $\quad$ (1) 2125735000

Website: www.fordfoundation.org

The Ford Foundation was established on 15 January, 1936, with an initial gift of US\$25,000 from Edsel Ford, whose father Henry, founded the Ford Motor Company. During its early years, the foundation operated in Michigan under the leadership of Ford family members. Since the founding charter stated that resources should be used 'for scientific, educational and charitable purposes, all for the public welfare,' the foundation made grants to many kinds of organizations.

\section{Ford Foundation Predoctoral Fellowships for Research-Based PhD or ScD Programs in United States of America}

Purpose: The fellowships are available for pursuing predoctoral level

Eligibility: All citizens, nationals, and permanent residents (holders of a Permanent Resident Card) of the United States, and individuals granted deferred action status under the Deferred Action for Childhood Arrivals Program, regardless of race, national origin, religion, gender, age, disability, or sexual orientation; individuals with evidence of superior academic achievement (such as grade point average, class rank, honors or other designations); individuals committed to a career in teaching and research at the college or university level; individuals enroled in or planning to enrol in an eligible research-based (dissertation-required), program leading to a $\mathrm{PhD}$ or $\mathrm{ScD}$ degree at a non-proprietary United States educational institution. For detailed information, please check website

Level of Study: Research

Type: Fellowship

Value: Annual stipend: US\$20,000. Award to the institution in lieu of tuition and fees US\$2,000. Expenses paid to attend at least one Conference of Ford Fellows

Length of Study: 3 years

Country of Study: United States of America

Application Procedure: The mode of applying is online

Closing Date: 14 November

Contributor: Ford Foundation

For further information contact:

Email: fordapplications@nas.edu

\section{Foreign Affairs and International Trade Canada}

Enquiries Service Foreign Affairs Canada, 125 Sussex Drive, Ottawa, ON K1A 0G2, Canada.

Tel: $\quad$ (1) 6139444000

Email: enqserv@dfait-maeci.gc.ca

Website: www.dfait-maeci.gc.ca 
Foreign Affairs and International Trade Canada supports Canadians abroad, helps Canadian companies succeed in global markets, promotes Canada's culture and values and works to build a more peaceful and secure world.

\section{Graduate Research Awards for Disarmament, Arms Control and Non-Proliferation}

Purpose: To enhance Canadian graduate-level scholarship on disarmament, arms control and non-proliferation issues

Eligibility: The competition is open to Canadian citizens and Canadian permanent residents/landed immigrants currently enrolled in a graduate programme. Graduate students studying outside Canada are eligible to apply but please note that funding to cover the cost of successful applicants' travel to Ottawa for the event at Global Affairs Canada is limited to domestic travel within Canada (or the equivalent). In order to expand the community of Canadian scholars working on non-proliferation, arms control and disarmament (NACD) issues, employees of Global Affairs Canada, and previous recipients of a Graduate Research Award are not eligible.

Level of Study: Doctorate, Postgraduate

Value: awards of C $\$ 5,000$ are available to Canadian Master's

Frequency: Annual

Country of Study: Canada

No. of awards offered: 4

Closing Date: 15 March

Funding: Government

No. of applicants last year: 4

Additional Information: For more information, please contact Elaine Hynes at The Simons Foundation by email to ehy nes@thesimonsfoundation.ca www.thesimonsfoundation.ca/ projects/graduate-research-awards-disarmament-arms-controland-non-proliferation

\section{For further information contact:}

Tel: $\quad$ (1)778 7827779

Email: ehynes@thesimonsfoundation.ca

\section{Forgarty International Center}

\section{Ecology and Evolution of Infectious Diseases Initiative (EEID)}

Purpose: This joint National Institutes of Health (NIH) National Science Foundation (NSF) initiative supports efforts to understand the underlying ecological and biological mechanisms that govern relationships between human-induced environmental changes and the emergence and transmission of infectious diseases

Eligibility: Check the website for further details.

Level of Study: Graduate

Type: Funding support

Frequency: Annual

Country of Study: Any country

Closing Date: 18 November

Funding: Private

\section{For further information contact:}

Fogarty International Center, National Institutes of Health, Building 31, B2C39, Bethesda, MD 20892-2220, United States of America.

Tel: $\quad$ (1) 3014961653

Fax: (1) 3014020779

Email: Christine.Jessup@nih.gov

\section{PhD Fellowship}

Purpose: The Boehringer Ingelheim Fonds (BIF) awards $\mathrm{PhD}$ fellowships to European citizens working in Europe or overseas and to non-European citizens pursuing their $\mathrm{PhD}$ projects in Europe.

Eligibility: The basic monthly stipend amounts to $€ 1,650$. In most countries, fellows are paid an additional flat rate of $€ 150$ per month to cover minor research-related costs (books, travel expenses, etc.). To adjust, e.g. for differences in living costs, country-related premiums may be added (in the United Kingdom, Austria, and the Netherlands currently $€ 650$, in the USA $€ 1,175$, in Switzerland $€ 1,600$, in Canada and Sweden $€ 600$, in Denmark and Belgium €700, and in Germany €200). Depending on the cost of living, most other countries are grouped into one of these categories. For example, an unmarried fellow working in Germany currently receives $€ 2,000$, in the USA $€ 2,975$, in the United Kingdom $€ 2,450$, and in Switzerland $€ 3,400$.

Level of Study: Postgraduate

Closing Date: 1 October

Additional Information: www.bifonds.de/fellowshipsgrants/phd-fellowships/who-can-apply-phd.html

\section{Forum Transregional Studies}

Wallotstrae 14, D-14193, Berlin, Germany.

The Forum Transregional Studies in Berlin is a research organization on the content internationalization of the humanities and social sciences. 


\section{Forum Transregional Studies Postdoctoral Fellowships for International Students}

Purpose: By creating a space of dialogue for university and museum scholars from all regions, it aims to discuss the potentials and contours of a plural history of art

Eligibility: International students are eligible to apply for this fellowship. Applicants whose first language is not English are usually required to provide evidence of proficiency in English at the higher level required by the University

Type: Postdoctoral fellowship

Value: In particular cases, shorter fellowship terms may be considered. Postdoctoral fellows will receive a monthly stipend of $€ 2,500$ plus supplements depending on their personal situation. Organizational support regarding visas, insurances, housing, etc. will be provided. Successful applicants become fellows of the program Art Histories and Aesthetic Practices at the Forum Transregionale Studien and are expected to take up residence in Berlin

Country of Study: Germany

Application Procedure: PDF files: 1. a curriculum vitae (in English). 2. a project description (no longer than five pages / in English). 3. a sample of scholarly work (about 20 pages of an article, conference paper, or dissertation chapter) names of two referees (including their e-mail addresses). The complete application should be submitted latest by 15 January and addressed to arthistories_application@trafo-berlin.de

Closing Date: 15 January

Additional Information: For more details please browse the link www.scholarshipsads.com/forum-transregional-studiespostdoctoral-fellowships-germany-2018-19/

\section{For further information contact:}

Email: arthistories_application@trafo-berlin.de

\section{Foundation for Digestive Health and Nutrition}

4930 Del Ray Avenue, Bethesda, MD 20814, United States of America.

Tel:

(1) 3012224002

Email: awards@fdhn.org

Website: www.fdhn.org

Contact: Ms Wykenna S.C.Vailor, Research Awards Manager

The Foundation for Digestive Health and Nutrition is the foundation of the American Gastroenterological Association (AGA), the leading professional society representing gastroenterological and hepatologists worldwide. It is separately incorporated and governed by a distinguished board of AGA physicians and members of the lay public. The Foundation raises funds for research and public education in the prevention, diagnosis, treatment and cure of digestive diseases. Along with the AGA, it conducts public education initiatives related to digestive diseases. The Foundation also administers the disbursement of grants on the behalf of the AGA and other funders.

\section{American Gastroenterological Association - Elsevier Pilot Research Award}

Purpose: To provide non-salary funds for new investigators to help them establish their research careers or to support pilot projects that represent new research directions for established investigators. The intent is to stimulate research in gastroenterology- or hepatology-related areas by permitting investigators to obtain new data that can ultimately provide the basis for subsequent grant applications of more substantial funding and duration

Eligibility: Applicants must possess an MD or PhD degree or equivalent and must hold faculty positions at accredited North American institutions. In addition, they must be AGA members at the time of application submission. Women and minorities are strongly encouraged to apply

Level of Study: Postdoctorate, Postgraduate, Predoctorate, Research

Type: Grant

Value: US $\$ 25,000$

Length of Study: 1 year

Frequency: Annual

Application Procedure: Applications can be downloaded from the AGA Foundation website. The completed application, letters of support or commitment and other documents must be submitted as one PDF document, titled by the applicant's last name and first initial only. Hard copies are not permitted. For further information visit the AGA Foundation website

No. of awards offered: 22

Closing Date: 12 January

Funding: Private

Contributor: The AGA

For further information contact:

Tel: (1) 3012224012

\section{American Gastroenterological Association Fellowship to Faculty Transition Awards}

Purpose: To prepare physicians for independent research careers in digestive diseases 
Eligibility: Applicants must be MDs or MD/PhDs currently in a gastroenterology-related fellowship, at a North American institution and committed to academic careers. They should have completed at least 2 years of research training at the start of this award. Women and minority investigators are strongly encouraged to apply. Applicants must be AGA Trainee Members or be sponsored by an AGA Member at the time of application

Level of Study: Postgraduate

Type: Award

Value: US $\$ 40,000$ per year

Length of Study: 2 years

Frequency: Annual

Application Procedure: Applications can be downloaded from the AGA Foundation website. The completed application, letters of support or commitment and other documents must be submitted as one PDF document, titled by the applicant's last name and first initial only. Hard copies are not permitted. For further information visit the AGA Foundation website

No. of awards offered: 8

Closing Date: 31 August

Funding: Private

Contributor: The AGA

\section{For further information contact:}

Tel: (1) 3012224012

\section{American Gastroenterological Association R Robert and Sally D Funderburg Research Scholar Award in Gastric Cancer}

Purpose: To support active, established investigators in the field of gastric biology who enhance the fundamental understanding of gastric cancer pathobiology in order to ultimately develop a cure for the disease

Eligibility: Applicants must hold faculty positions at accredited North American institutions and must have established themselves as independent investigators in the field of gastric biology. Women and minority investigators are strongly encouraged to apply. Applicants must be members of the AGA at the time of application submission

Level of Study: Postgraduate

Type: Award

Value: US $\$ 100,000$

Length of Study: 2 years

Frequency: Annual

Country of Study: The United States of America, Canada or Mexico

Application Procedure: Applications can be downloaded from the AGA Foundation website. The completed application, letters of support or commitment and other documents must be submitted as one PDF document, titled by the applicant's last name and first initial only. Hard copies are not permitted. For further information visit the AGA Foundation website

No. of awards offered: 1

Closing Date: 29 July

Contributor: The AGA, the late R Robert and the late Sally D Funderburg

No. of applicants last year: 1

For further information contact:

Tel: (1) 3012224012

\section{American Gastroenterological Association Research Scholar Awards}

Purpose: To enable young investigators to develop independent and productive research careers in digestive diseases by ensuring that a major proportion of their time is protected for research

Eligibility: Candidates must hold an $\mathrm{MD}, \mathrm{PhD}$, or equivalent degree and a full-time faculty positions at North American universities or professional institutes at the time of commencement of the award. They must be members of the AGA at the time of application submission. The award is for young faculty, who have demonstrated unusual promise and have some record of accomplishment in research. Candidates must devote at least $70 \%$ of their efforts to gastrointestinal tract or liver-related research. Women, minorities and physician/scientist investigators are strongly encouraged to apply

Level of Study: Graduate

Type: Research grant

Value: US $\$ 100,000$ per year

Length of Study: 3 years

Frequency: Annual

Country of Study: United States of America

Application Procedure: Applications can be downloaded from the AGA Foundation website. The completed application, letters of support or commitment and other documents must be submitted as one PDF document, titled by the applicant's last name and first initial only. Hard copies are not permitted. For further information visit the AGA Foundation website

No. of awards offered: 4

Closing Date: 10 November

Funding: Private

Additional Information: www.gastro.org/research-andawards/research-awards/apply-for-awards/award/aga-researchscholar-award-rsa 


\section{For further information contact:}

Tel: (1) 3012224012

\section{American Gastroenterological Association/ American Gastroenterological Association-Eli \& Edythe Broad Student Research Fellowship(s)}

Purpose: To stimulate interest in research careers in digestive diseases by providing salary support for research projects Eligibility: Applicants must be students at accredited North American institutions, may not hold similar salary support awards from other agencies. Women and minority students are strongly encouraged to apply

Level of Study: Graduate, Postgraduate, Professional development

Type: Award

Value: US $\$ 2,500$ to 3,000 per year

Length of Study: 10 weeks

Frequency: Annual

Application Procedure: Applications can be downloaded from the AGA Foundation website. The completed application, letters of support or commitment and other documents must be submitted as one PDF document, titled by the applicant's last name and first initial only. Hard copies are not permitted. For further information visit the AGA Foundation website

No. of awards offered: 48

Closing Date: 1 June

Funding: Private

Contributor: The AGA

For further information contact:

Tel: (1) 3012224012

\section{Foundation for Liberal and Management Education University}

Gat No. 1270, Lavale, Off. Pune Bangalore Highway, Pune, Maharashtra 412115, India.

Contact: Foundation for Liberal and Management Education University

FLAME University is a private, coeducational and fully residential university, anchored in liberal education located in Pune city in the state of Maharashtra. Earlier it was known as FLAME - Foundation for Liberal and Management Education.

\section{Foundation for Liberal and Management Education University Scholars Program}

Purpose: The scholarship is designed to give students an opportunity to further their education at FLAME University

Eligibility: Students from India are eligible to apply

Type: Postgraduate scholarships

Value: FLAME University offers a range of scholarships that recognize the inherent excellence and distinctive attributes of students ensuring that FLAME attracts the brightest of minds. In addition, merit, need-based and special scholarships are provided with that may range from partial to full fee waivers

Study Establishment: Scholarships are awarded to study the students offered by the university

Country of Study: India

Application Procedure: To be considered for the scholarship, students need to email the supporting documents of achievements at admission-at-flame.edu.in. FLAME University's Scholarship Committee will evaluate your application and make the final decision

Additional Information: For more details please browse the website www.flame.edu.in/academics/flame-scholarsprogram

For further information contact:

Tel: $\quad$ (61) 8002094567

Email: enquiry@flame.edu.in

\section{Foundation for Science and Disability, Inc.}

1700 SW 23rd Dr, Gainesville, FL 32608, United States of America.

Tel:

$$
\text { (1) } 3523745774
$$

Email:_richard.mankin@ars.usda.gov

Website: stemd.org

Contact: Dr Richard Mankin, Chair, Student Grants

The Foundation for Science and Disability aims to promote the integration of scientists with disabilities into all activities of the scientific community and of society as a whole, and to promote the removal of barriers in order to enable students with disabilities to choose careers in science. 


\section{Foundation for Science and Disability Student Grant Fund}

Subjects: Engineering, mathematics, medicine, natural sciences and computer science.

Purpose: To increase opportunities in science for graduatelevel students who have disabilities.

Eligibility: Open to candidates from the USA.

Level of Study: Doctorate, Postgraduate

Type: Grant

Value: US $\$ 1,000$

Length of Study: 1 year

Frequency: Annual

Country of Study: United States of America

Application Procedure: Applicants must submit a completed application form, copies of official college transcripts, a letter from the research or academic supervisor in support of the request and a second letter from another faculty member.

No. of awards offered: 1 to 3

Closing Date: 1 December

Funding: Private

No. of awards given last year: 1

No. of applicants last year: 8

Additional Information: The award may be used for an assistive device or instrument, or as financial support to work with a professor on an individual research project or for some other special need. www.stemd.org/

\section{For further information contact:}

\section{Email: Richard.Mankin@USDA.GOV}

\section{Graduate Student Grant}

Purpose: The Student Award Program of FSD helps to increase opportunities in science, engineering, mathematics, technology, and pre-medical/dental areas for graduate or professional students with disabilities. FSD has established a Science Graduate Student Grant Fund, which is available to fourth year undergraduates (who are disabled and have been accepted to a graduate or professional school in the sciences) and graduate science students who have a disability. Awards of US\$1000 each are made to support research projects of qualified university students in any field of Mathematics, Science, Medicine, Technology, or Engineering

Eligibility: graduate students with a disability who have a research program in a science, technology, engineering or mathematics program

Level of Study: Doctorate, Graduate, Postgraduate (MSc)

Type: Award/Grant
Value: US $\$ 1,000$

Length of Study: 1 year

Frequency: Annual

Country of Study: United States of America

Application Procedure: application form must be completed. Two letters of reference. Copy of passport or birth certificate

No. of awards offered: 11

Closing Date: 1 December

Funding: Foundation

Contributor: Foundation for Science and Disability

\section{Foundation of the American College of Healthcare Executives}

Suite 1700, One North Franklin Street, Chicago, IL 606064425, United States of America.

Tel: $\quad$ (1) 3124249388

Email:_membershipl@ache.org

Website: www.ache.org

Contact: The Membership Marketing Representative

It is the mission of the Foundation of the American College of Healthcare Executives to be the professional membership society for healthcare executives; to meet its members' professional, educational and leadership needs; to promote high ethical standards and conduct; and to advance healthcare leadership and management excellence.

\section{Albert W Dent Graduate Student Scholarship}

Purpose: Albert W. Dent, the first African-American Fellow of ACHE. This scholarship is offered to provide financial aid to racially/ethnically students in healthcare management graduate programs to help offset tuition costs, student loans and expenses.

Eligibility: 1. You are a racially/ethnically diverse student enrolled full-time in a healthcare management graduate program - MHA, MPH, MBA in Healthcare Administration or similar. 2. You are entering your final year (fall/spring) of fulltime study. 3. You expect to graduate or have graduated between Sept. 1, 2021 and Aug. 31, 2022. 1. If you have a residency as part of your program and the upcoming fall term will be your second year of study, you may apply for a scholarship. 2. If you have already completed your classroom work and are in the residency part of your program, you are not eligible to apply. 3. Doctoral students are also not 
eligible to apply. 4. You are not required to be a Student Associate of the American College of Healthcare Executives. However, during the selection process, preference is given to applicants who are Student Associates of ACHE. 5. You can demonstrate financial need. 6. You are a U.S. citizen or lawful permanent resident; or a Canadian citizen.

Level of Study: Graduate

Type: Scholarship

Value: Each scholarship is worth US $\$ 5,000$

Frequency: Annual

Country of Study: United States of America or Canada

Application Procedure: 1. Complete the online application in its entirety. 2. Be sure to include the following with your application: 3. Current resume or curriculum vitae 3. Official undergraduate and graduate transcripts 4 . Three current letters of recommendation (one must be from your graduate program director) 5. Application Essay including information on your: 1. Reason for pursuing a career in healthcare management / your career aspirations and goals 2. History in the field 3. Financial need 4. Community/Civic engagement and volunteerism

No. of awards offered: 15

Closing Date: 31 March

\section{For further information contact:}

Email: membership@ache.org

\section{Foster G McGaw Graduate Student Scholarship}

Purpose: To help students better prepare themselves for a career in healthcare management

Eligibility: You may apply for a Foster G. McGaw Graduate Student Scholarship if you meet all of the following criteria: 1. You are a student enrolled full-time in a healthcare management graduate program - MHA, MPH, MBA in Healthcare Administration or similar. 2. You are entering your final year (fall/spring) of full-time study. 3. You expect to graduate or have graduated between Sept. 1, 2021 and Aug. 31,2022 . 4. If you have a residency as part of your program and the upcoming fall term will be your second year of study, you may apply for a scholarship. 5. If you have already completed your classroom work and are in the residency part of your program, you are not eligible to apply. 6. Doctoral students are also not eligible to apply. 7. You are not required to be a Student Associate of the American College of Healthcare Executives. However, during the selection process, preference is given to applicants who are Student Associates of ACHE. 8. You can demonstrate financial need. 9. You are a U.S. citizen or lawful permanent resident; or a Canadian citizen.

Level of Study: Graduate
Type: Scholarship

Value: Each scholarship is worth US\$5,000

Frequency: Annual

Country of Study: United States of America or Canada

Application Procedure: Applications are accepted between Jan. 2 and March 31. All applicants will be notified about the status of their applications by letter in June. 1. Current resume or curriculum vitae 2. Official undergraduate and graduate transcripts 3 . Three current letters of recommendation (one must be from your graduate program director)

No. of awards offered: 15

Closing Date: 31 March

\section{For further information contact:}

Email: contact@ache.org

\section{Foundation Praemium Erasmianum}

Jan van Goyenkade 5, NL-1075 HN Amsterdam, Netherlands.

Tel: $\quad$ (31) 206760222

Email: spe@erasmusprijs.org

Website: www.erasmusprijs.org

Contact: Y C Goester, Secretary

The Foundation Praemium Erasmianum operates internationally in the fields of social studies and the arts and humanities, through the awarding of the Erasmus Prize and other activities.

\section{Foundation Praemium Erasmianum Study Prize}

Purpose: To honour young academics who have written an excellent thesis in the field of humanities or social sciences

Eligibility: Open to students of Dutch universities

Level of Study: Postdoctorate

Type: Money prize

Value: $€ 3,000$

Frequency: Annual

Country of Study: Any country

Application Procedure: Relevant faculties or universities nominate candidates, from which the Foundation selects five winners

No. of awards offered: 21

Closing Date: 15 July

Funding: Private 


\section{For further information contact:}

Email:1.aalbers@erasmusprijs.org

\section{Freie Universitat Berlin and Peking University}

No.5 Yiheyuan Road Haidian District, 100871 Beijing, P.R.China.

Email: beate.rogler@fu-berlin.de

Website: www.fu-berlin.de

Contact: Freie Universitat Berlin and Peking University

\section{Free University of Berlin and Peking University Joint Postdoctoral Fellowship}

Purpose: Applications are invited for Freie Universitat Berlin and Peking University Joint Postdoctoral Fellowship Program awarded for the duration of 24 months, starting 1 November. The fellowship is open to highly qualified researchers of all nationalities who received their $\mathrm{PhD}$ no more than three years prior to the deadline for this call

Eligibility: Applicants of all nationalities are eligible to apply. Applicants whose first language is not English are usually required to provide evidence of proficiency in English at the higher level required by the University

Type: Postdoctoral fellowship

Value: During their stay in Berlin, the Joint Postdoctoral Fellows will receive a monthly stipend of $€ 1,853$ and a one-time relocation allowance of $€ 2,000$. They are eligible for a monthly child allowance if travelling to Berlin with dependent children. All Fellows will furthermore have access to the Researcher Development Program of the Dahlem Research School. During their stay at PKU, Joint Postdoctoral Fellows will receive a monthly stipend of RMB 15,000 . They can receive an additional RMB 3,500 per month for self-organized accommodation or choose to live in a PKU postdoc flat. The Fellows are furthermore eligible to apply for travel funding. They will have access to China's Postdoctoral Funds or other national research funds upon registration at the Office of National Postdoctoral Affairs Management Committee

Study Establishment: Area Studies, Data Science \& Mathematics, Each fellowship is awarded for 24 months, starting 1 November. It consists of two phases Phase 112 months of research at FUB (November to October) Phase 212 months of research at PKU The Fellowship applicants must identify and secure the endorsement of two tenured faculty members, one at each university, who will serve as hosts. They will conduct their research projects under the
Country of Study: Any country

Application Procedure: Please refer the website

Closing Date: 22 February

Additional Information: Please browse the website for more details www.fu-berlin.de/en/sites/china/aktuelles/news/ 2017_11_FUB_PKU_Joint-Postdoc.html

\section{For further information contact:}

Email: judith.winkler@fu-berlin.de

\section{French Ministry of Foreign Affairs}

Website: www.campusfrance.org/en/eiffel

\section{Eiffel Scholarships in France for International Students}

Purpose: The Eiffel Excellence Scholarship Programme was established by the French Ministry of Foreign Affairs and International Development to enable French higher education establishments to attract top foreign students to enroll in their master's and $\mathrm{PhD}$ courses

Level of Study: Doctorate, Postgraduate

Type: Scholarship

Value: For masters level studies, the Eiffel scholarship includes a monthly allowance of $€ 1,181$ (a maintenance allowance of $€ 1,031$ and a monthly stipend of $€ 150$ ) and can be awarded for 1 to 3 years. For PhD level studies, the Eiffel scholarship includes a monthly allowance of $€ 1,400$ and is awarded for a maximum of 10 months

Length of Study: 1 to 3 years

Frequency: Annual

Study Establishment: French Universities and Academic Institutions

\section{Country of Study: France}

Application Procedure: Only applications submitted by French higher education institutions are accepted

Closing Date: 8 January

Contributor: French Ministry of Foreign Affairs and International Development

Additional Information: Please visit Official Scholarship Website: www.campusfrance.org/en/eiffel-scholarshipprogram-of-excellence

\section{For further information contact:}

Campus France - Programme Eiffel, 28 rue de la Grange-auxBelles, F-75010 Paris, France.

Email: candidatures.eiffel@campusfrance.org 


\section{Friends of Israel Educational Foundation}

Academic Study Group, POB 42763, London N2 0YJ, United Kingdom.

Tel: (44) 2084440777

Email: info@foi-asg.org

Website: www.foi-asg.org

Contact: Mr John D A Levy

The Friends of Israel Educational Foundation and its sister operation, the Academic Study Group, aim to encourage a critical understanding of the achievements, hopes and problems of modern Israel, and to forge new collaborative working links between the United Kingdom and Israel.

\section{Friends of Israel Educational Foundation Academic Study Bursary}

Purpose: To provide funding for British academics planning to pay a first research or study visit to Israel

Eligibility: Open to research or teaching postgraduates. The Academic Study Group will only consider proposals from British academics who have already linked up with professional counterparts in Israel and agreed terms of reference for an initial visit

Level of Study: Postdoctorate

Type: Bursary

Value: $£ 300$ per person

Frequency: Annual

Country of Study: Israel

Application Procedure: Applicants must contact the organization. There is no application form

No. of awards offered: Approx. 50

Closing Date: 1 May

Funding: Private

Contributor: Trusts and individual donations

\section{Fujitsu}

1250 E. Arques Avenue, Sunnyvale, CA 94085-3470, United States of America.

Fujitsu is the Japanese global information and communication technology (ICT) company, offering a full range of technology products, solutions and services.

\section{Fujitsu Scholarship Program for Asia-Pacific Region}

Purpose: Applications are invited for Fujitsu Scholarship program open to applicants of United States of America and Asia pacific region. The scholarship provides full financial assistance for postgraduate education and cross-cultural management training in the Global Leaders for Innovation and Knowledge program at JAIMS, the Japan-America Institute of Management Science in Hawaii, United States of America Eligibility: A minimum TOEFL score of 577/233/90 (paper/ computer/Internet), TOEIC score of 750 , or IELTS (Academic) overall band test result of 6.5 or higher from a test taken within the last five years at the time of application Type: Postgraduate scholarships

Value: See the website

Study Establishment: Scholarship is awarded for education and cross-cultural management training in the Global Leaders for Innovation and Knowledge program by Fujitsu-JAIMS Foundation

Country of Study: United States of America

Application Procedure: See the website

Closing Date: 7 March

Additional Information: For more details please visit the website scholarship-positions.com/fujitsu-scholarshipprogram-asia-pacific-region-usa/2013/12/07/

\section{For further information contact:}

Tel:

(33) 810447543413

Email: Dina.Tiongson@au.fujitsu.com

\section{Fulbright Commission (Argentina)}

Viamonte 1653, 2 Piso, C1055 ABE, Buenos Aires, Argentina.

Tel: $\quad$ (54) 1148143561

Email: info@fulbright.com.ar

Website: fulbright.edu.ar/en

Contact: Melina Ginszparg, Educational Advisor

The Fulbright Programme is an educational exchange programme that sponsors awards for individuals approved by the J William Fulbright Board. The programme's major aim is to promote international co-operation and contribute to the development of friendly, sympathetic and peaceful relations between the United States and other countries in the world. 


\section{Fulbright Commission (Argentina) Awards for United States Lecturers and Researchers}

Purpose: To enable United States lecturers to teach at an Argentine university for one semester, and to enable United States researchers to conduct research at an Argentine institution for 3 months

Eligibility: Open to United States researchers and lecturers. Applicants must be proficient in spoken Spanish

Level of Study: Professional development

Value: Varies according to professional experience

Length of Study: 3 months

Frequency: Annual

Country of Study: Argentina

Closing Date: 31 July

Funding: Government

Contributor: The United States of America and the Argentine governments

\section{For further information contact:}

The Council for International Exchange of Scholars, 3001 Tilden Street, Washington, DC 20008-3009, United States of America.

Tel: (1) 2026864000

Email: info@ciesnet.cies.org

\section{Fulbright Scholar-in-Residence}

Purpose: To enable visiting scholars to teach in the United States about their home country or world region

Eligibility: Open to candidates with strong international interest and some experience in study abroad and exchange programmes

Level of Study: Professional development

Type: Grant

Value: Fulbright funding plus salary supplement and in-kind support from the host institution

Length of Study: 1 year

Frequency: Annual

Application Procedure: Candidates must submit a Fulbright visiting scholar application form and a brief project statement

Closing Date: March

\section{For further information contact:}

Tel: (33) $148143561 / 62$

Email: sir@iie.org

\section{Fulbright Foundation (United Kingdom)}

Fulbright House, 62 Doughty Street, London WC1N 2LS, United Kingdom.

Tel: $\quad$ (44) 2074046880

Contact: Grants Management Officer

\section{British-American Chamber of Commerce Awards}

Purpose: To fund postgraduate education between Britain and America

Eligibility: Open to graduates of any nationality

Level of Study: Postgraduate

Value: US\$8,000

Frequency: Annual

Country of Study: United States of America

Application Procedure: Please write for details.

\section{For further information contact:}

Email: fulbrighttgc@irex.org

\section{Fulbright Scholarship Program for Nigerians}

Purpose: The Fulbright Scholarship program for Nigerians is offering Scholarships to students of Nigeria who are interested in pursuing two years doctoral studies in United States of America, in the fields of natural and social sciences, arts, and humanities

Eligibility: Applicants must be a resident of the state of Hawaii, USA, or a citizen of one of the following countries: Australia, Cambodia, China, Hong Kong, India, Indonesia, Laos, Malaysia, Myanmar, New Zealand, the Philippines, Singapore, South Korea, Sri Lanka, Taiwan, Thailand, or Vietnam. Applicants who are residents of the State of Hawaii will be requested to prove Hawaii residency.

Level of Study: Doctorate

Type: Scholarship

Value: It includes all related expenses

Length of Study: 2 years

Frequency: Annual

Country of Study: United States of America

Application Procedure: 1. To apply for the Fulbright Scholarship for Nigerians the applicants must be citizens or nationals of Nigeria, or permanent residents holding a valid passport issued by the government of Nigeria. 2. The applicants must be doctoral students who conducted research in 
their home institution, applicants must be at least two years into their doctoral program in any discipline that was related to the subjects offered by the university

Funding: Private

Additional Information: Young and talented scholars of Nigeria are invited to apply for Fulbright Scholarship Program for Nigerians to pursue doctoral studies in United States of America scholarship-positions.com/fujitsu-scholarshipprogram-asia-pacific-region-usa/2013/12/07/

\section{For further information contact:}

Email: professionalexchange@state.gov

\section{Fulbright United States Student Program}

\section{Fulbright-National Geographic Digital Storytelling Fellowship}

Purpose: The Fulbright-National Geographic Storytelling Fellowship, a component of the Fulbright United States Student Program, provides opportunities for United States citizens to participate in an academic year of overseas travel

Eligibility: Applications will be accepted for FulbrightNational Geographic Storytelling Fellowships in any country to which there is an active Fulbright United States Student Program with the exception of China

Level of Study: Postgraduate, Professional development

Type: Fellowship

Frequency: Annual

Country of Study: Any country

Application Procedure: Candidates must have completed at least an undergraduate degree by the commencement of the Fulbright awa Candidates from all fields are encouraged to apply. All application materials, including academic transcripts and letters of recommendation must be submitted in the Embark Online Application and Recommendation System by 9 October at 5pm Eastern Time

Closing Date: 9 October

Funding: Private

\section{For further information contact:}

United States Student Programs Division, 809 United Nations Plaza, New York, NY 10017 3580, United States of America.

Email: FBstudent.natgeo@iie.org

\section{Fund for Epilepsy}

Ripponden Mill, Mill Fold, Ripponden, Halifax H6 4DH, United Kingdom.

Tel: $\quad$ (44) 1422823508

Email: ffe@epilepsyfund.org.uk

Website: www.epilepsyfund.org.uk

Contact: The Administrator

\section{Emergency Medicine Foundation Grants}

Purpose: To aid various ethnic minority voluntary organizations

Value: Dependent, for 1-3 years

Frequency: Dependent on funds available

Application Procedure: Please write in to EMF, grants officer Funding: Government, Individuals

\section{For further information contact:}

Tel: $\quad$ (44) 2084320000 Free phone : (44) 80006520390

Fax: (44) 2084320319

Email: enquiries@emf-cemvo.co.uk

\section{Fundacion Educativa Carlos M. Castaneda}

1925 Brickell Ave, Miami, FL 33129, United States of America.

Tel: $\quad$ (1) 3052834963

Email: fecmc@me.com

Website: www.fecmc.org

We are a community-based organization focused on helping make the world around us a better, happier place. With the help of our tireless staff, we organize fundraisers, exciting community-building events, and in-depth training sessions for our volunteers.

\section{Carlos M. Castaeda Journalism Scholarship}

Purpose: This award is for Spanish speaking students who are pursuing a graduate degree in journalism. Applicants must have a grade point average of 3.0 or higher 
Eligibility: 1. Must be a graduate student 2. Must attend a university 3. Minimum 3.0 GPA 4. Must be at least 20 years old 5. Must not be older than 35 years old 6 . Must study full-time 7. Restricted to students studying Communications, Journalism, Photojournalism/Photography 8. Restricted by ethnic heritage: Hispanic, Spanish

Level of Study: Graduate

Type: Scholarship

Value: US\$7,000

Frequency: Annual

Country of Study: United States of America

Application Procedure: Applications and award information are available on the Carlos M. Castaeda Educational Foundation website at the address provided. In addition to the completed online application form, students must submit the following items: Official transcripts of all academic work completed; Proof of acceptance in an accredited graduate program; Recent 1,040 documents or equivalent information describing the student and his/her parents' financial status; Recent curriculum vitae describing the applicant's work history and activities; Three letters of reference in separately sealed envelopes; A portfolio showcasing three recently written works that have been published in the Spanish language

Closing Date: 15 April

Funding: Foundation

No. of awards given last year: 1

\section{For further information contact:}

1925 Brickell Avenue D-1108, Miami, FL 33129, United States of America.

\section{Funds for Women Graduates}

57 Alma Road, Leeds LS6 2AH, United Kingdom.

Tel:

Email:

(44) 1132747988

Website:

secretary@ffwg.org.uk

www.ffwg.org.uk

Contact: Mrs Sally Dowell, Co. Secretary

FFWG is the registered Trading Name for the BFWG Charitable Foundation. FfWG seeks to promote the advancement of education and the promotion of higher education of women graduates by offering grants to help women graduates with their living costs while registered for study or research at institutions in Great Britain.

\section{Emergency Grants}

Subjects: Any subject

Purpose: The criteria for awarding Grants are the proven needs of the applicant and her academic calibre. Competition is very great so not all qualifying applicants will receive a Grant. Grants are offered on a needs basis therefore not all grants will be for the maximum sum quoted for the grant.

Eligibility: Please see website for details. www.ffwg.org.uk Level of Study: Postgraduate

Type: Grant

Value: Up to $£ 2,500$

Length of Study: Any postgraduate course eligible

Frequency: Twice a year

Study Establishment: Any approved institution of higher education in Great Britain

Country of Study: England, Scotland and Wales

Application Procedure: Please see website for details. www. ffwg.org.uk

Closing Date: 18 May

Funding: Private

Contributor: Investment funds

For further information contact:

4 St Michaels Gate, Shrewsbury SY1 2HL, United Kingdom.

Email: grants@ffwg.org.uk

\section{Emergency Grants for United Kingdom and International Women Graduates}

Purpose: To allow a woman facing unexpected financial crises to continue in postgraduate study

Eligibility: Women graduates from Britain and overseas are eligible to apply. There is no upper age limit

Type: Grant

Value: These are one off payments to assist with the completion of an academic years work. No grant is likely to exceed $£ 2,500$. All grants are offered on a needs basis and therefore not all grants will be for $£ 2,500$

Country of Study: United Kingdom

Application Procedure: The mode of applying is by post. An application form for an Emergency Grant may be obtained by email only from the Grants Administrator at grants@ffwg.org.uk No. of awards offered: 170

Closing Date: 5 October

Funding: Private

Additional Information: All grants are offered on a needs basis scholarship-positions.com/fujitsu-scholarship-programasia-pacific-region-usa/2013/12/07/ 


\section{For further information contact:}

Email: grants@ffwg.org.uk

\section{FfWG Foundation Grants}

Purpose: To financially assist female graduates registered for study or research at an approved Institute of Higher Education within Great Britain

Eligibility: Open to female graduates who are in their final year or writing-up year of a $\mathrm{PhD}$ There is no restriction on nationality or age. Any subject

Level of Study: Doctorate, Postdoctorate, Postgraduate Type: Grant

Value: Foundation Grants are up to $£ 4,000$ and Emergency Grants are up to $£ 1,500$. (these values are being reviewed)

Length of Study: Courses that exceed 1 year in length

Frequency: Annual

Study Establishment: Approved Institutes of Higher Education

Country of Study: Great Britain

Application Procedure: Applicants must complete an application form and submit it with two references and a brief summary of the thesis, if applicable. Requests for application forms must be made by email

No. of awards offered: 376

Closing Date: 31 May

Funding: Private

Contributor: Investment income

Additional Information: Closing dates are liable to change each year. Please refer to our website for details of the current year www.fundsforngos.org/global-fund-for-women/ffwgsgrants-helping-women-graduates/

\section{For further information contact:}

Email: grants@ffwg.org.uk

\section{Foundation Grants}

Purpose: FfWG offers Foundation Grants to help women graduates with their living expenses (not fees) while registered for study or research at an approved institution of higher education in Great Britain. The criteria are the proven needs of the applicant and her academic calibre. Foundation Grants will only be given for the final year of a PhD or DPhil. The closing date for applications for current and upcoming year is 5 March and the grants are awarded in July for the following academic year. Request for applications must be made by 28 February

Eligibility: For your application to be considered you must meet all the eligibility conditions which may be found on the 'Am I Eligible' (www.ffwg.org.uk/am-i-eligible-.html) page of the site. In brief, to be eligible you must be a woman postgraduate studying in Great Britain at an approved higher education institution (typically a university) and entering the final year for completing your PhD (or equivalent) thesis. Applications may only be made for financial support with living costs (not for fees) where there is genuine financial need to complete the course of study.

Level of Study: Doctorate

Type: Grant

Value: Up to $£ 6,000$

Frequency: Annual

Study Establishment: Any recognised university

Country of Study: United Kingdom, Scotland and Wales Application Procedure: please see website for details www. ffwg.org.uk

No. of awards offered: 309

Closing Date: 5 March

Funding: Private

Contributor: Investment income

Additional Information: Please contact grants@ffwg.org.uk www.ffwg.org.uk/our-grants.html

\section{For further information contact:}

Sally Dowell, 57 Alma Road, Leeds LS6 2AH, United Kingdom.

\section{Theodora Bosanquet Bursary}

Subjects: History or English Literature

Purpose: This Bursary is offered annually to women graduates whose research in History or English Literature requires a short residence in London in the summer. It provides accommodation in a hall of residence for up to 4 weeks between end of June and mid September. The closing date for applications is 31 st October of the preceding year.

Eligibility: Please see website for details. www.ffwg.org.uk Level of Study: Postgraduate

Type: Bursary

Value: Up to four weeks accommodation

Frequency: Once a year

Country of Study: England, Scotland and Wales

Application Procedure: Please see website for details. www.

ffwg.org.uk

No. of awards offered: 2

Funding: Private

Contributor: Investment funds

No. of awards given last year: 1

No. of applicants last year: 1 
Additional Information: Please contact grants@ffwg.org.uk for further details www.advance-africa.com/TheodoraBosanquet-Bursary.html

\section{Fylde College}

Email: fylde@lancaster.ac.uk

\section{Fylde College - Travel Award}

Purpose: The scholarship is available to enable Fylde students to travel to: 1. Conferences or training. 2. Dissertation locations where costs exceed that normally expected as part of the degree course. 3 . Undertake voluntary work in vacation time

Eligibility: For further information, refer the official website link

Level of Study: Undergraduate and Postgraduate

Type: Travel award

Value: A total fund of $£ \$ 1,500$ is available

Frequency: Annual

Country of Study: Any country

Application Procedure: Please ask in the Fylde College office for an application form or visit https://www.lancaster. ac.uk/fylde/welfare-and-support/financial-support/.

Funding: Private

\section{For further information contact:}

Tel: (44) 152465201 